\title{
Development of Learning Media Tutorial on Audio-Visual
}

\author{
Aan Deki Praja Pane \\ Graduate Student of Sport Education \\ Universitas Negeri Medan, Indonesia \\ Email:aandekiprajapane@gmail.com
}

\author{
Imran Akhmad \\ Graduate Lecturer of Sport Education \\ Universitas Negeri Medan, Indonesia
}

\author{
Sanusi Hasibuan \\ Graduate Lecturer of Sport Education \\ Universitas Negeri Medan, Indonesia
}

\begin{abstract}
Abstrak - Physical Education is a part of education as a whole can play an important role in the achievement of educational goals, learning media is something that can channel messages to students so that the learning process is created. The purpose of this research is to produce Audio-Visual Tutorial learning media for freestyle swimming material for high school. this study uses the development model from Borg and Gall which was adapted into a simple model, namely: determining the potential and problems of research, gathering information, needs analysis, product design and design validation, media expert test, swimming expert test, physical education learning expert test, trial small group, revise the results of the trial, large group trials, revise the results of the trial, final product development. The final product from the development of Audio-Visual Tutorial media is continued to the effectiveness test. This research will be carried out in Labuhan Deli, Deli Serdang Sumatera Utara Indonesia. The target in the research of developing audio-visual learning media in this Tutorial is all Physical Education Teachers and Senior High School Students as equals. From the results of the discussion note that the audio-visual tutorial learning media is very helpful for teachers in the learning process in Senior high school as equals, and audio-visual learning media is very effective for use in physical education learning freestyle swimming material.
\end{abstract}

\section{Keywords: Development, Learning Media, Physical Education}

\section{INTRODUCTION}

Turning from the industrial era to the information age or better known as the ICT-based era is forcing changes in various fields, including in the field of sports. Sports which so far have more psychomotor activity compared to cognitive activities and their effectiveness should be able to utilize current technology in an effort to develop sports education. Education is a conscious and planned effort to realize the learning atmosphere and learning process so that students actively develop their potential to have the spiritual power of religion, self-control, personality, intelligence, noble character, and skills needed by themselves, society, nation and State. Education can also be referred to as Guidance or help given by adults to the development of a child to reach maturity with the aim that the child is capable enough to carry out his own life duties not with the help of others.

Learning is the process of interacting students with educators and learning resources in a learning environment. Learning is assistance provided by educators so that knowledge and knowledge acquisition, mastery of skills and character can occur, as well as the formation of attitudes and beliefs in students. In the context of education, the teacher teaches that students can learn and master the content of the lesson until it reaches an objective that is determined. Learning is a system that aims to help the student learning process, which contains a series of events designed, arranged in such a way.

Physical education is a process of education of a person as an individual or a member of society that is carried out consciously and systematically through various physical activities to obtain physical growth, health and physical fitness, abilities and skills, intelligence and development of character and harmonious personality in the framework of quality Indonesian human formation based on Pancasila. According to Lutan (2000:6) explains that: "The term physical education is an activity that is educational by utilizing physical activities, including sports. According to Aip Syarifudin, et al, (2009:3) Physical education is a process through physical activity, which is designed and arranged systematically to stimulate growth and development, improve physical abilities and skills, intelligence and character formation, as well as values and positives for each citizen State in order to achieve educational goals.

Learning media is everything that can channel messages, can stimulate students' thoughts, feelings, and wishes so that they can encourage the learning process in students. Learning media is a physical means to convey learning content/materials such as: books, films, videos and so on. according to Sadiman (2008:14) learning media as one of the learning resources that can channel messages so that they can help. Daryanto (2016:7) learning media is a process of communication. Hamalik (1994: 6) learning media as a communication tool to make the teaching and learning process more effective. Furthermore according to Arsyad (2007:2) learning media is an integral part of the teaching and learning process in order to achieve educational goals in general and the objectives of learning in schools in particular.

According to Suleiman (1985:11) audio-visuals are tools that are audible which means they can be heard and visible tools mean they can be seen. This media is also a sensor aids, what is meant is the sensory speaker assistive devices. or also with the term audio-visual communication, which means audio-visual communication. Arsyad (2007: 94) audio-visual is the writing of texts and storyboards that require a lot of preparation, plans, and research. Sulaiman (1985:190) 
describes sound films, television and video including pure audio-visual media because these three devices combine sound and visual functions in one unit. Audio-visual learning media in the form of View Compact Disc (VCD) Tutorial is one of the learning media that can help the teaching and learning process, this media can also provide a more detailed explanation by stopping impressions on certain movements, so that those who watch the show can be more clear, in addition to pictures and the resulting sound will make the show more attractive so that the viewer is interested in paying attention to the material in the Tutorial VCD All material that is in the Physical Education learning requires media, one of them is swimming material.

According to Badruzaman (2007:13) swimming is "an attempt to float or lift the body by a person to move his body in the water. Thomas $(2006: 1)$ Swimming sports are the most useful water sports arts regarding the ability to float, rotate, bend, turn around, sinking, arising, and rotating in a place without weight that can bring pleasure and also a recreation for the body that is not right or tired According to Kasiyo Dwijowinoto (1979:1) Swimming is one of the sports that can be taught at all ages, good children and adults, babies who are several months old can also be taught swimming. According to Arma Abdoelah (1981:270) Definition of swimming is a type of exercise that is carried out in water, both in fresh water and in salt or sea water. According to Muhajir (2004:166) Swimming is a sport that can provide health for the body. Because almost all the limbs are used in doing the sport. And also in every muscle of the body will develop rapidly so that it can give an increase in the strength of a fast swimmer. According to Rahmani (2017:2) Swimming can be divided into several types of functions, namely swimming as a means of leisure and swimming. Both have similarities, which are carried out in ponds and other waters, such as river lakes and seas.

In learning Physical Education requires the teacher to teach all the material in the Physical Education curriculum, the amount of material that the teacher will teach students is certainly not easy for a teacher, to master and have all the materials or learning media that will be delivered to students is very difficult, for example material freestyle swimming. Freestyle swimming is included in the Physical Education curriculum so at school we find freestyle swimming learning. According to Nana Sudjana (2005) the curriculum is the intention $\&$ hope that is poured into the form of plans and educational programs carried out by educators in schools. The curriculum is as intention \& plan, while the implementation is the teaching and learning process. Hamalik (2014:18) defines the curriculum as a set of plans and arrangements regarding content and teaching materials and the methods used as guidelines for the implementation of teaching and learning activities. Furthermore Harsono (2005) reveals that the curriculum is an idea of education expressed through practice. Understanding the current curriculum is growing, so that what is meant by the curriculum is not only as an idea of education, but all planned learning programs from national education institutions. In the learning process in the school the Physical Education teacher must understand how to teach freestyle swimming material supported by the media, tools, facilities so that it can be accepted by students.

The reality is that the learning process is not going well because the teacher finds it difficult to find learning media that suits the needs of students, thus causing Sports and Physical Education teachers to find it difficult to teach free style swimming material and students find it difficult to understand and accept the freestyle swimming material taught by the teacher. Another thing was also found in the district Labuhan Deli, Deli Serdang Sumatera Utara Indonesia schools during freestyle swimming learning, the teacher found it difficult to find freestyle swimming learning media so that the teacher only taught by using tools or books without being supported by learning media, resulting in a lack of students' understanding of the material taught by the teacher and results in low student learning outcomes.

Based on the experience of researchers during being a Physical Education teacher, researchers saw students having difficulty understanding free-style swimming material, especially when doing movements and explanations given by the teacher. Researchers searched for various learning resources on the internet or youtube, researchers found the Freestyle Technique by Speedo swimming learning video, according to the video researchers were not in accordance with the needs of teachers and students. Freestyle Technique by Speedo video swimming has no text, only an oral explanation using English so that it is difficult for teachers and students to review or digest the contents of the video, besides that the Freestyle Technique by Speedo video also has not described well the stages and sequence of motion in accordance with the learning of Physical Education freestyle swimming material. According to the Freestyle Technique by Speedo swimming learning video researcher, it needs to be developed to meet the needs of Sports and Physical Education teachers.

The video that will be developed by researchers is an audio-visual learning media tutorial on freestyle swimming material. With the development of audio-visual learning media, the freestyle swimming material tutorial will be very helpful and easier for Sports and Physical Education teachers in understanding and teaching the freestyle swimming material, the Sports and Physical Education teacher can also teach it to students at school. then the teacher and students can learn independently at home to better understand freestyle swimming material through audio-visual learning media on the freestyle swimming material tutorial.

With the statements above, the researcher conducted an initial research or needs analysis conducted on August 14-15, 2017 in several schools in the district Labuhan Deli, Deli Serdang Sumatera Utara Indonesia, researchers conducted surveys and interviews in the form of questionnaires with 10 teachers and 20 students. From the results of the questionnaire, it can be seen that teachers who have been teaching Physical Education in Senior high school for more than 3 years are equal to $80 \%$, teachers who have difficulty teaching $80 \%$ freestyle swimming material, teachers who have been looking for $70 \%$ freestyle swimming learning media and $70 \%$ teachers who difficulty finding freestyle swimming learning media, $70 \%$ of teachers did not find the freestyle swimming learning 
media, then $100 \%$ of teachers who desperately needed audiovisual learning media freestyle swimming tutorials. Furthermore, all teachers are interested in audio-visual learning media tutorials for freestyle swimming material for senior high school equivalent to be developed.

From the questionnaire data it can be concluded that it is necessary to develop an audio-visual learning media for high school freestyle swimming material tutorials that can be used as a free style swimming learning media by Physical Education teachers, so that it becomes a solution to support the Physical Education learning process, and is expected to improve results student learning. This is also a clue that the Audio-Visual learning media for senior high school freestyle swimming material equivalent to be developed must be used by teachers as teaching materials or independent learning for students.

\section{METHOD}

Research development of instructional media audio-visual tutorial materials freestyle swimming for the equivalent of senior high school is using a model development Research \& Development (R \& D) of Borg and gall (1989:775) consists of ten steps: (1) research and data collection (measurement needs research on a small scale) (2) planning, research plans (formulate objectives,) (3) development of product form (development of learning materials, learning and evaluation instruments) (4) initial field trials (using 6-12 subjects) (5) revise (enhance test results) (6) the main field test (with 30100 subjects) (7) improvement of products, field test results (8) test field implementation (with 40-200 subjects) (9) to improve products end (10) dissemination and implementation (reporting the results in professional meetings and in journals, in collaboration with the publisher for publishing. Monitoring the distribution for quality control.

This free style swimming learning development product planning is quoted from Sadiman, Arif. S. (2003) as for the following steps:

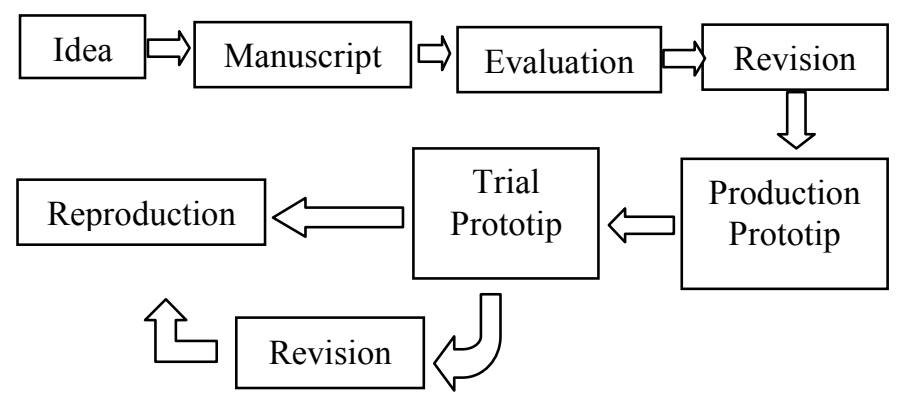

Fig. 1. Steps of Borg \& Gall (1989)

After producing the product, then test the product in order to obtain the data used as the basis for determining the feasibility of the product developed by the researcher. The stages in this trial trial are: 1) determine the trial design, 2) determine the subjects to be tested, 3) determine the type of data, 4) establish data collection instruments 5) data analysis techniques. The design of this trial aims to obtain the data needed to improve the product as a whole. The design of this trial includes two stages, namely the first stage evaluation and the second stage evaluation, the second stage of this evaluation has the purpose of getting information about the truth of the product being developed.

Trial subjects included (1) the subject of needs analysis as many as 10 teachers and 20 students, (2) Phase I trials, the subjects of this trial consisted of 30 teachers who were taken using purposive sample techniques (3) Phase II trials, the subject of this trial consisted of 40 teachers. This development research uses qualitative data, because the data produced is expressed by sentences and not by numbers. While quantitative data is obtained by changing qualitative to quantitative data by giving a score on the qualitative data. The instrument used in this study was in the form of a questionnaire to determine needs analysis, expert evaluation/pool training questionnaire, physical education learning expert evaluation questionnaire, and media expert evaluation questionnaire and the results of the teacher assessment (in phase I trials and phase II trials). The instrument used was in the form of a litigation questionnaire, this questionnaire aimed to determine the needs analysis, expert evaluation/trainer questionnaire questionnaire, physical education learning expert evaluation questionnaire, and media expert evaluation questionnaire and the results of the teacher assessment (in phase I trials and phase II trials) Needs identification instrument in this study was prepared with the aim to obtain data on teachers' opinions on what they were using, and what learning media the teacher wanted. The initial and main field test instruments are prepared based on the evaluation concept of the teachers. This development research uses quantitative descriptive data analysis techniques with percentages. This technique is used to analyze quantitative data obtained from the results of distributing questionnaires to evaluations from swimming experts/trainers, physical education learning experts and media experts on the product developed. To process data using the following formula:

a. Formula for processing data per respondent:

Information:

$$
P=\frac{X}{X I} \times 100 \%
$$

$\mathrm{p}=$ percentage from the evaluation results of the trial respondents

$\mathrm{X}=$ the number of answer answers by the test respondents

$\mathrm{Wi}=$ number of optimal answers in the aspect of assessment by the trial respondents

$100 \%=$ constant

b. the formula for processing the data of the whole respondents of the trial.

$$
P=\frac{\Sigma X}{\sum X_{i}} \times 100 \%
$$

Information: $\mathrm{P}=$ percentage results from the overall evaluation of the respondents' trials. $\sum X=$ the total number of respondents' answers in the overall aspects of the Assessment. 
$\sum X=$ the total number of respondents' maximum score in the overall assessment aspect. $100 \%=$ constant

In determining the conclusions that have been reached, the criteria are set as in the table below:

\section{TABLE 1. CRITERIA OF PRODUCT VALIDITY}

\begin{tabular}{|c|l|l|l|}
\hline NO & PERCENTAGE & INFORMATION & MEAN \\
\hline 1. & $80 \%-100 \%$ & Valid & Used \\
\hline 2. & $60 \%-79 \%$ & Enough valid & Used \\
\hline 3. & $50 \%-59 \%$ & Less valid & replaced \\
\hline 4. & $<50 \%$ & Invalid & replaced \\
\hline
\end{tabular}

Formulas for processing the results of responses or evaluations from each teacher from the results of giving product response questionnaires and formulas that will be used are:

\section{Score $=\frac{\text { Amount of Score }}{\text { Total Score }} \times 100$}

For the average category, the Effectiveness value is as follows:

\begin{tabular}{|c|c|c|}
\multicolumn{2}{c|}{ TABLE 2. CATEGORY OF PRODUCT EFFECTIVENESS } \\
\hline NO & VALUE & CATEGORY \\
\hline 1. & $\geq 80$ & Very Effective \\
\hline 2. & $60-79$ & Effective \\
\hline 3. & $40-59$ & Enough Effective \\
\hline 4. & $30-39$ & Less Effective \\
\hline 5. & $<29$ & Very Less Effective \\
\hline
\end{tabular}

\section{RESEARCH RESULT}

The results of the research development of Audio-Visual learning media Tutorial freestyle swimming material that uses this VCD are starting from:

\section{a. Need analysis}

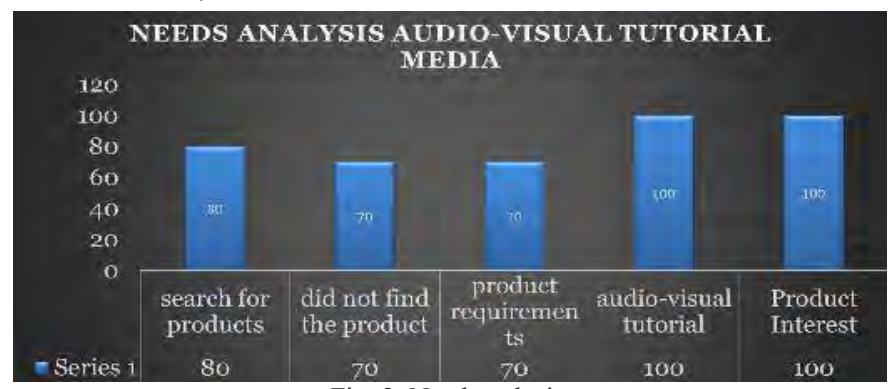

Fig. 2. Need analysis.

From the results of the above needs analysis, it is stated that teachers and students are in desperate need of audio-visual learning media From the results of the above needs analysis, it is stated that teachers and students are in desperate need of audio-visual learning media tutorials for freestyle swimming. The teacher and students also said that it was necessary to develop audio-visual learning media products for free freestyle swimming for high school students tutorials for freestyle swimming. The teacher and students also said that it was necessary to develop audio-visual learning media products for free freestyle swimming for senior high school students.

\section{b. Expert trial}

After obtaining the data from the needs analysis, the script is then made and then the manuscript is revised by an expert for product feasibility. The results of the expert trial can be seen in the table chart below:

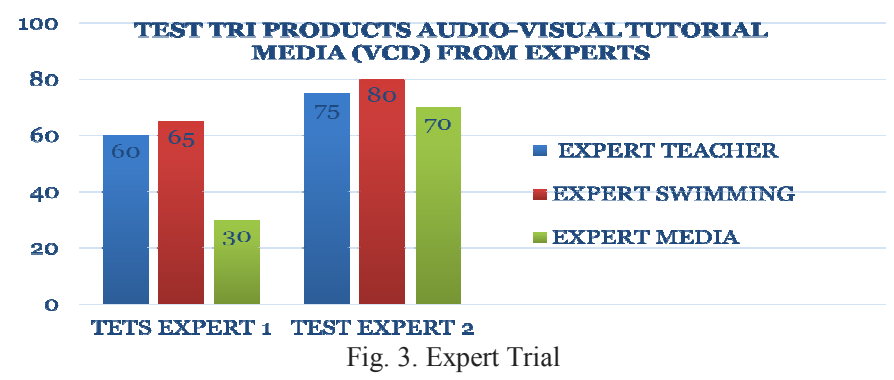

After conducting one and two expert trials, the next can be continued by testing the effectiveness of the product to the teacher and students.

\section{c. Test the effectiveness For physical education teachers}

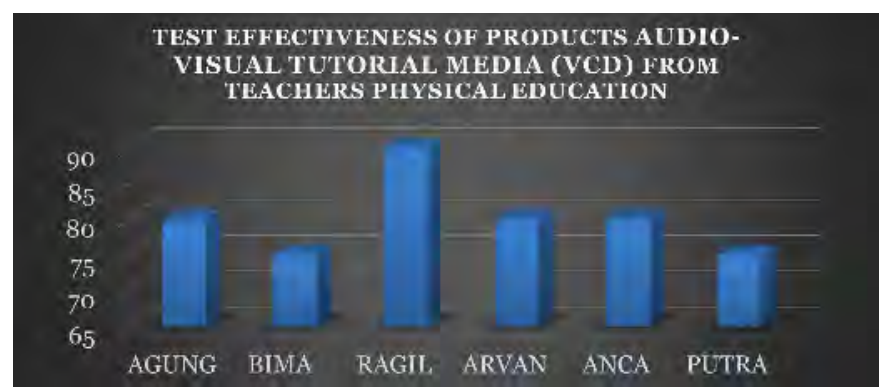

Fig. 4. Test the effectiveness For physical education teachers

Based on the results of the effectiveness test for physical education teachers that the audio-visual learning media of freestyle swimming material tutorials are very effective in helping the learning process.

\section{d. Test the effectiveness for senior high school students.}

TEST EFFECTIVENESS OF VCD PRODUCTS FROM STUDENTS SENIOR HAIG SCHOOL (SMA)

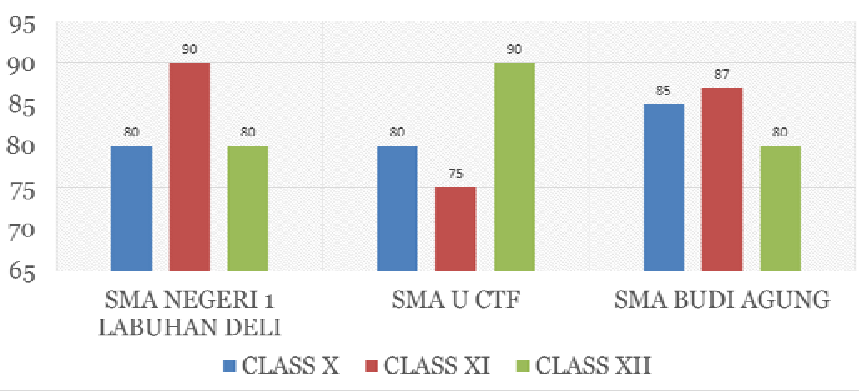

Fig. 5. Test the effectiveness for senior high school students. 
Based on the results of the effectiveness test for senior high school students that the audio-visual learning media of freestyle swimming material is very effective in helping the learning process and can be used as independent learning material by students.

\section{CONCLUSIONS}

Based on the data collected from the field trials and the results of the discussion of the research, it can be concluded that learning using the freestyle swimming material audio visual tutorial (VCD) learning media is very helpful for the teacher in the swimming learning process. This freestyle swimming material audio visual tutorial (VCD) also makes it easy for students to understand the material and can also help students learn independently. With the development of swimming learning media that researchers develop teachers and students can also more easily learn basic techniques of freestyle swimming material.

\section{References}

[1] Aip Syarifudin, dkk.2009. pendidikan jasmani dan pemanfaatannya Bandung: Raja Grafindo.2016. Olahraga paling lengkap. Jakarta: PT serambi semesta distribusi

[2] Ali,M., Asrori, M.2016. Metodologi \& Aplikasi Riset Pendidikan. Jakarta:Bumi Aksarayad, Azhar. 2007. Media Pembelajaran. Jakarta: Raja Grafindo

[3] Asyhar. 2011. Media pembelajaran dan petunjuk penyusunan. Yogyakarta: Gava Media

[4] Cheryl A Coker. 2004. Motor Learning and controlpractitioners. New Mexico: Mcgrawhill.

[5] Daryanto. (2010). Media Pembelajaran Peranannya Sangat Penting Dalam Mencapai Tujaun Pembelajaran. Yogyakarta: Gava Media

[6] Daryanto. 2016. Media Pembelajaran. Yogyakarta: Gava Media

[7] Dwiyogo. D. Walsis. 2004. Konsep penelitian \&pengembangan. Disajikan pada lokakarya metodologi penelitian jurusan kepelatihan fakultas ilmu keolahragaan universitas negeri semarang. Malang: Universitas Negeri Malang
[8] Freeman. 2001. pendidikan jasmani dan pemanfaatannya.Jakarta:Remaja Rosdakarya

[9] Ibrahim. 2005. Media Pembelajaran. Malang: Lab, Teknologi Pendidikan Fakulta Pendidikan Univeritas Negeri Malang.

[10] Kurniawan, A.w. 2009. Pengembangan Pembelajaran JudoTeknik Banting KYU 4 Dengan Media VCD Untuk Pejudo PJSI (Persatuan Judo seluruh Indonesia). Jakarta:Unuversitas Negeri Jakarta

[11] Latuheru, jhon. D. 1988. Media pembelajaran dalam proses belajar mengajarmaa kini.

[12] Lutan.2000. pendidikan jasmani untuk sekolah menengah atas. Jakarta:Raja Grafindo

[13] Muhajir. 2004. dasar dasar renang dan pemanfaatannya. Jakarta, PT. Gava Media

[14] Nohantiya.2016. Pengembangan VCD Instruksional peregangan aktif (Ative Stretching) kebugaran jasmani siswa smp dimalang. Jurnal Multilateral, Volume 15, No. 2 hlm. 101-110.

[15] Nuruana. 2007. Model pembelajaran creative problem solving dengan video compact disk dalam pembelajaran.

[16] Nursalim. 2010. Media pembelajaran dan pengembangan. Jakarta, PT. Rosda Kenanga.

[17] Rahmani.2017.Buku pintar renang. Jakarta PT. Anugrah.

[18] Rusman. (2012). Belajar dan Pembelajaran Berbasis Komputer Mengembangkan Profesionalisme Guru Abad 21. Bandung: Alfabeta.

[19] Sadiman, Arif,S.dkk. 2008. Media Pendidikan pengertian, pengembangan dan pemanfaatannya. Jakarta:Raja Grafindo

[20] Sugiono. 2015. Metode Penelitian Pendidikan Pendekatan Kuantitatif, Kualitatif Dan R\&D. Bandung:Alfabeta

[21] Soejoko, Hendromartono. 1992. Olahraga Pilihan Renang. Jakarta : Proyek Pembinaan Tenaga Kependidikan Depdikbud.

[22] Sukintoko dan Sukarno. 1983. Renang dan Metodik. Jakarta, PT. Rosda Jayaputra.

[23] Sulaiman, Amir Hamzah.1985. Media-visual untuk pengajaran, penerangan dan penyuluhan.. jakarat:Gramedia.

[24] Susilana, Rudi. Ryana, Cepi. 2009. Media Pembelajaran Hakikat, Pengembangan, Pemamfaatan, dan Penilaian. bandung: CV Wacana Prima.

[25] Syarifudin. 2000. pendidikan jasmani disekolah. Bandung:Remaja Rosdakarya.

[26] Thomas, David G. 2007. Renang Tingkat Pemula. (Terjemahan Alfons) Jakarta: PT Raja Grafindo Persada.

[27] Tim pascasarjana unimed.2015. pedoman administrasi dan penulisan tesis \& disertasi. Medan:unimed 